\title{
Bacillus velezensis CE 100 Inhibits Root Rot Diseases (Phytophthora spp.) and Promotes Growth of Japanese Cypress (Chamaecyparis obtusa Endlicher) Seedlings
}

\author{
Jae-Hyun Moon ${ }^{1}$, Sang-Jae Won ${ }^{1}$, Chaw Ei Htwe Maung ${ }^{2}$, Jae-Hyeok Choi ${ }^{1}$, Su-In Choi ${ }^{1}$, Henry B. Ajuna ${ }^{1}$ \\ and Young Sang Ahn $1, *$ (D)
}

1 Department of Forest Resources, College of Agriculture and Life Sciences, Chonnam National University, Gwangju 61186, Korea; mjh132577@naver.com (J.-H.M.); lazyno@naver.com (S.-J.W.); cjh960728@gmail.com (J.-H.C.); suin917@naver.com (S.-I.C.); ajunahenry@mmu.ac.ug (H.B.A.)

2 Division of Agricultural and Biological Chemistry, Institute of Environmentally Friendly Agriculture, College of Agriculture and Life Sciences, Chonnam National University, Gwangju 61186, Korea; chaweihtwemaung@gmail.com

* Correspondence: ysahn@jnu.ac.kr; Tel.: +82-62-530-2081; Fax: +82-62-530-2089

Citation: Moon, J.-H.; Won, S.-J.; Maung, C.E.H.; Choi, J.-H.; Choi, S.-I.; Ajuna, H.B.; Ahn, Y.S. Bacillus velezensis CE 100 Inhibits Root Rot Diseases (Phytophthora spp.) and Promotes Growth of Japanese Cypress (Chamaecyparis obtusa Endlicher) Seedlings. Microorganisms 2021, 9, 821. https://doi.org/ 10.3390/microorganisms 9040821

Academic Editor: José

David Flores-Félix

Received: 18 March 2021

Accepted: 11 April 2021

Published: 13 April 2021

Publisher's Note: MDPI stays neutral with regard to jurisdictional claims in published maps and institutional affiliations.

Copyright: (c) 2021 by the authors. Licensee MDPI, Basel, Switzerland. This article is an open access article distributed under the terms and conditions of the Creative Commons Attribution (CC BY) license (https:// creativecommons.org/licenses/by/ $4.0 /)$.

\begin{abstract}
Root rot diseases, caused by phytopathogenic oomycetes, Phytophthora spp. cause devastating losses involving forest seedlings, such as Japanese cypress (Chamaecyparis obtusa Endlicher) in Korea. Plant growth-promoting rhizobacteria (PGPR) are a promising strategy to control root rot diseases and promote growth in seedlings. In this study, the potential of Bacillus velezensis CE 100 in controlling Phytophthora root rot diseases and promoting the growth of C. obtusa seedlings was investigated. $B$. velezensis CE 100 produced $\beta$-1,3-glucanase and protease enzymes, which degrade the $\beta$-glucan and protein components of phytopathogenic oomycetes cell-wall, causing mycelial growth inhibition of P. boehmeriae, P. cinnamomi, P. drechsleri and P. erythoroseptica by $54.6 \%, 62.6 \%, 74.3 \%$, and $73.7 \%$, respectively. The inhibited phytopathogens showed abnormal growth characterized by swelling and deformation of hyphae. B. velezensis CE 100 increased the survival rate of C. obtusa seedlings 2.0-fold and 1.7-fold compared to control, and fertilizer treatment, respectively. Moreover, B. velezensis CE 100 produced indole-3-acetic acid (IAA) up to $183.7 \mathrm{mg} / \mathrm{L}$, resulting in a significant increase in the growth of C. obtusa seedlings compared to control, or chemical fertilizer treatment, respectively. Therefore, this study demonstrates that $B$. velezensis CE 100 could simultaneously control Phytophthora root rot diseases and enhance growth of C. obtusa seedlings.
\end{abstract}

Keywords: forest seedling production; antagonistic bacteria; lytic enzymes; phytopathogenic oomycetes; auxin; plant development; biocontrol agent

\section{Introduction}

The Japanese cypress (Chamaecyparis obtusa Endlicher) is a conifer of the cypress family (Cupressaceae), cultivated in many parts of Asia, including Japan, China and Korea [1-5]. The wood of C. obtusa has been used for centuries for furniture and the construction of temples and other traditional buildings due to its natural fragrance, good quality and high durability in outdoor conditions $[1,4,5]$. In particular, C. obtusa has been commercially used in the production of perfumes, cosmetics, soap, toothpaste, and disinfectants in Korea, due to its fresh fragrance [4,5]. In Korea, the afforestation areas of $C$. obtusa has been gradually increased and it ranked the first, accounting for $28.9 \%$ of total seedlings produced in 2020 [6]. The intensive production of tree seedlings often requires the use of chemical fertilizers to improve nutritional balance for successful seedling growth [7]. However, the conventional system of forest seedling production often uses excessive chemical fertilizers. This leads to plant defects, increases disease susceptibility, accelerates soil erosion and reduces efficiency of nutrient re-uptake and soil fertility [8-10]. Moreover, intensive nitrogen fertilization 
has potential for increasing the proportion of phytopathogens in the soil, which could negatively affect tree seedlings [9].

In recent years, Chamaecyparis, a member of $C$. obtuse, which is susceptible to oomycete pathogens, has faced an increasing challenge of phytophthora root rot diseases during forest seedling production $[8,11,12]$. The genus Phytophthora has over 150 species and commonly occurs in water-saturated soils $[13,14]$. It is the most devastating causal agent of root and stem rot, causing discoloration, necrotic leaves and wilting of new growths, leading to death of forest seedlings [8,11,13-15]. Phytophthora root rot diseases in C. obtusa seedlings cause yellowing and brown colorations from the lower leaves, which extends to the upper canopy, leading to complete wilt. Similar symptoms were observed in this study (Figure 1B). The deciduous oblong shaped sporangia, produced by Phytophthora spp., induce root rot diseases by releasing large numbers of zoospores that are attached to the tips of young roots where they encyst, germinate and infect other roots $[11,16-18]$. After infection, the oomycete quickly colonizes the root system, causing death of plant tissue due to necrosis in the inner bark $[12,18]$. Ultimately, the entire canopy of infected seedlings progressively develops foliage symptoms, such as pale green, yellow and light brown coloration, leading to the death of the entire tree $[11,12,16]$. Due to the highly destructive nature of these pathogens, an effective disease management strategy is essential for ensuring healthy forest seedlings.
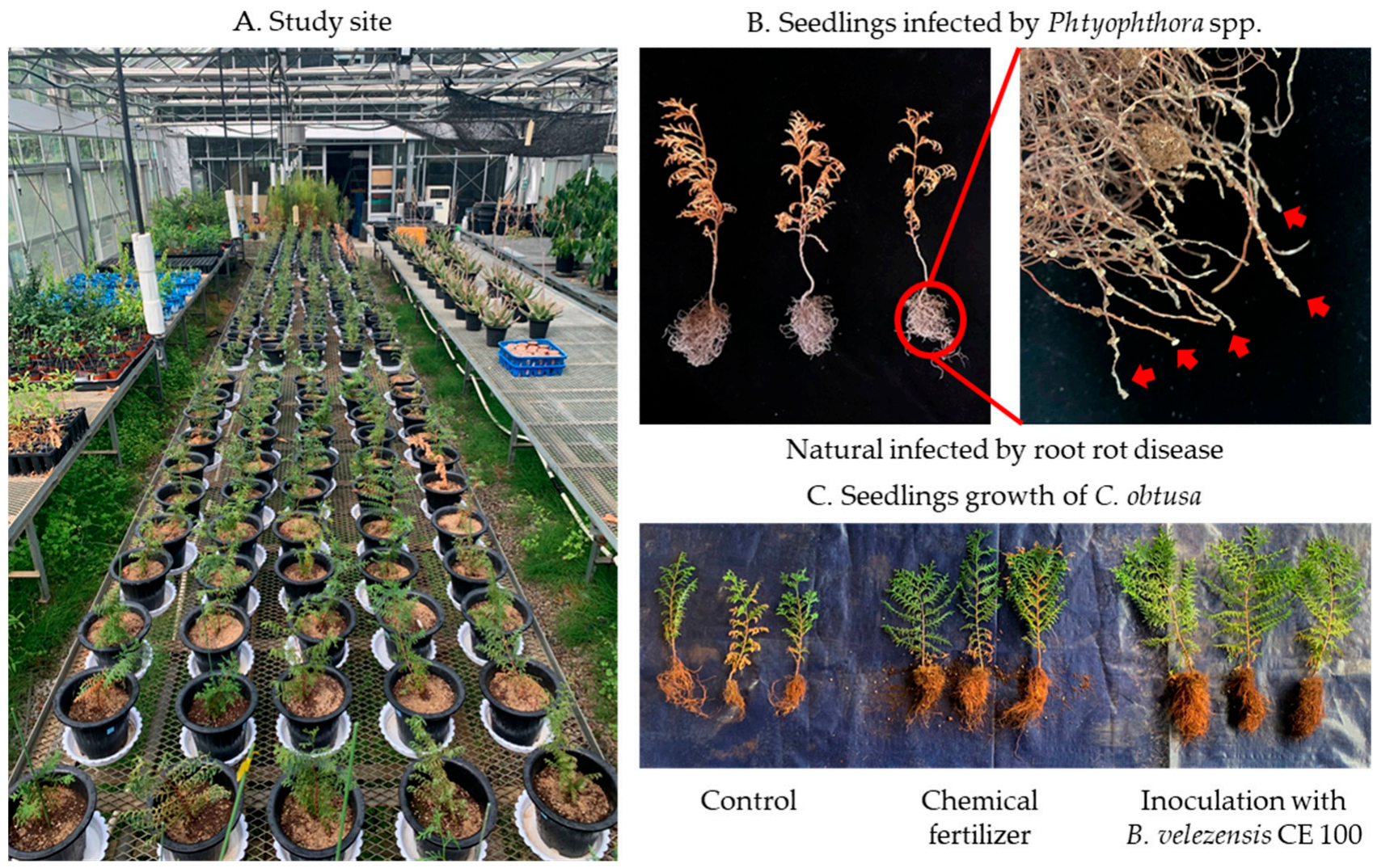

Natural infected by root rot disease

C. Seedlings growth of C. obtusa

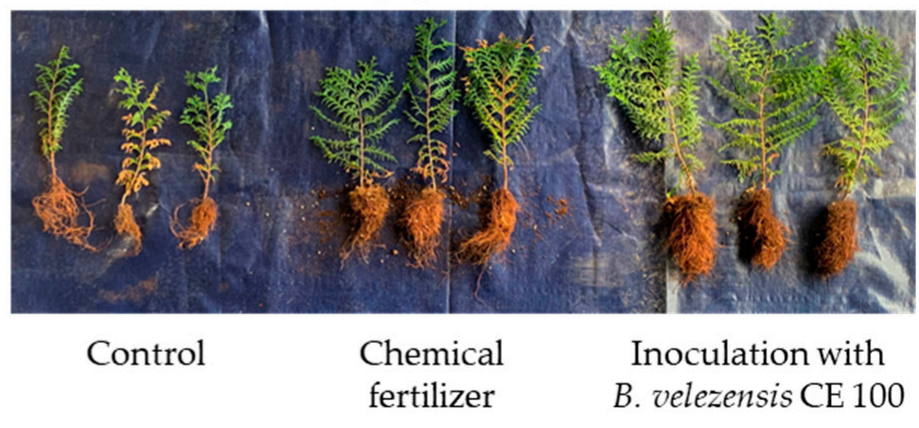

Figure 1. Study area in an experimental greenhouse at the forest nursery (A); seedlings infected by Phytophthora spp. (B); seedlings growth of control conditions, chemical fertilizer treatment and bacterial inoculation with B. velezensis CE 100 (C).

The use of chemical fungicides is the most widely used control method for suppressing the invasion of Phytophthora spp. in forest seedlings. However, frequent chemical fungicides cause environmental contamination and could lead to the development of resistant strains [19-21]. In addition, such chemicals also kill useful soil organisms and beneficial microbes in the root zone. Excessive chemical use also reduces soil fertility, pollutes water resources and consequently cause harmful effects on human health [21,22]. Due to the 
increasing concern about the environment and human health, biological control of plant diseases has received increased focus $[19,21]$. Among the various methods, the use of plant growth-promoting rhizobacteria (PGPR) has attracted attention of many researchers. PGPR can control pathogenic oomycetes and increase plant growth [23-28]. Moreover, PGPR are well-known non-toxic bacteria that enhance soil fertility without causing negative effects on human health and the environment [28]. In addition, PGPR can effectively boost plant health by limiting the growth of plant pathogens through the production of antagonistic substances, antibiotics and cell wall degrading enzymes [25-28]. Lytic enzymes, such as $\beta-1,3$-glucanase and protease produced by PGPR are key players in the degradation of oomycete cell walls, which are mainly composed of $\beta$-glucan and protein $[23,25,26,28,29]$. On the other hand, PGPR provides plants with phytohormones, such as auxins, gibberellins and cytokinins, which regulate plant growth [24,28,30-36]. In particular, PGPR secretes auxins, such as indole-3-acetic acid (IAA), which improve the growth of shoots and roots by increasing root surface area, which in turn, promote nutrient uptake $[23,24,28,30-39]$. Specifically, Bacillus species possess significant inhibitory activity against various phytopathogens, including Phytophthora capsici [40,41] and Phytophthora drechsleri [42]. In addition, Bacillus species are known to produce auxins, which promote plant growth [31-35].

In the field of forestry, the production of high-quality forest seedlings that are infectionfree is the most important factor for a successful nursery [43,44]. Well-developed, healthy seedlings perform better than small, weak seedlings after transplanting, especially under competitive conditions with forest weeds [45]. However, increasing the production of highquality seedlings, while reducing the use of synthetic chemical fertilizers and fungicides, is a major challenge. Many PGPR species have been reported to improve plant growth and to control root rot pathogens. However, the potential of PGPR in the management of Phytophthora root rot diseases and growth promotion of C. obtusa seedlings has not been described. For sustainable production of high-quality cypress seedlings, it is important to understand the inhibitory mechanisms employed by PGPR against phytopathogens, as well as the biochemical interactions that influence seedling development. Therefore, the objective of this study was to investigate the effects of Bacillus velezensis CE 100 on the inhibition of Phytophthora spp., and the subsequent management of Phytophthora root rot diseases as well as growth promotion of C. obtusa seedlings.

\section{Materials and Methods}

\subsection{Preparation of B. velezensis CE 100 and Phytophthora spp.}

Bacterial strains B. velezensis CE 100, used in this study, were isolated from pot soils of tomato plants [46]. Then, B. velezensis CE 100 was streaked onto tryptone soy agar (TSA) medium and inoculated at $30^{\circ} \mathrm{C}$ for 3 days. To examine the growth conditions and activities of lytic enzymes ( $\beta-1,3$-glucanase and protease) produced by strain $B$. velezensis $C E 100$, pink broth (PB) (pink fertilizer (NPK 20-20-20) $3 \mathrm{~g}, \mathrm{KH}_{2} \mathrm{PO}_{4} 0.2 \mathrm{~g}$, $\mathrm{MgSO}_{4} 0.2 \mathrm{~g}$, NaCl $0.1 \mathrm{~g}$, sucrose $3 \mathrm{~g}$, chitin powder $0.5 \mathrm{~g}$ and yeast extract $0.6 \mathrm{~g}$ in $1 \mathrm{~L}$ distilled water) medium was pre-inoculated with a loopful of $B$. velezensis $\mathrm{CE} 100$ colonies and cultured at $30^{\circ} \mathrm{C}$ in a shaking incubator (H1012 Incu-Shaker, Benchmark Scientific, Inc., Edison, NJ, USA) at $120 \mathrm{rpm}$ for 3 days [30-32,47]. Then, $200 \mu \mathrm{L}$ of this pre-inoculated bacterial culture broth $\left(10^{5}\right.$ colony-forming unit (CFU)/mL) was inoculated into $200 \mathrm{~mL}$ of PB broth, followed by incubation at $30^{\circ} \mathrm{C}$, with shaking at $120 \mathrm{rpm}$ in a shaking incubator for 10 days. The experiment was replicated three times. During incubation, samples were collected every day for 10 days. After serial dilution, samples were spread on TSA plates and incubated at $30^{\circ} \mathrm{C}$ for 1 day. The number of cells were counted as CFUs for each incubation day to determine the growth pattern of strain B. velezensis CE 100.

\subsection{Quantitative Analysis of Lytic Enzymes}

Protease activity was determined following the method described by Ghorbel-Frikha et al. [48]. Briefly, Tris buffer $(100 \mathrm{mM})$ containing $2 \mathrm{mM} \mathrm{CaCl}_{2}$ and $1 \%$ casein was prepared and adjusted to $\mathrm{pH}$ 8.0. A reaction mixture, containing $50 \mu \mathrm{L}$ of 
bacterial supernatant and $950 \mu \mathrm{L}$ of Tris buffer, was incubated at $60^{\circ} \mathrm{C}$ for $15 \mathrm{~min}$. Then $500 \mu \mathrm{L}$ of $20 \%$ trichloroacetic acid was added to terminate the reaction. The mixture was centrifuged at 13,000 rpm for $15 \mathrm{~min}$. The absorbance of the supernatant containing acidsoluble proteins was measured at $280 \mathrm{~nm}$ using a UV spectrophotometer (UV-1650PC, Shimadzu, Kyoto, Japan). One unit of protease activity was defined as the amount of enzyme that liberated $1 \mu \mathrm{g}$ of tyrosine per minute.

The activity of $\beta$-1,3-glucanase was determined using the method described by Liang et al. [49]. Briefly, a reaction mixture containing $50 \mu \mathrm{L}$ of bacterial supernatant, $50 \mu \mathrm{L}$ of laminarin $(10 \mathrm{mg} / \mathrm{mL}$ ) and $400 \mu \mathrm{L}$ of $50 \mathrm{mM}$ sodium acetate buffer (pH 5.0) was incubated at $37^{\circ} \mathrm{C}$ for $1 \mathrm{~h}$. The reaction was stopped by adding $1.5 \mathrm{~mL}$ of 3,5-dinitrosalicylic acid (DNS) reagent and boiled in a water bath for $5 \mathrm{~min}$. Absorbance at $550 \mathrm{~nm}$ was then measured to determine the concentration of reducing sugars. One unit of $\beta-1,3$-glucanase activity was defined as the amount of enzyme that catalyzed the release of $1 \mu \mathrm{mol}$ of glucose per hour at $37^{\circ} \mathrm{C}$.

\subsection{Anti-Oomycete Activity of B. velezensis CE 100 Against Phytophthora spp.}

During seedling growth of C. obtusa, root rot diseases symptoms, such as drying of leaves and eventual death of the seedlings, were observed (Figure 1B). Phytopathogenic oomycete isolates were isolated from diseased roots of 5 seedlings in each treatment. The isolates were identified as P. boehmeriae, P. cinnamomi, P. drechsleri, P. erythoroseptica based on 18s RNA gene sequence. Consequently, the oomycete pathogens $P$. boehmeriae (KACC 44718), P. cinnamomi (KACC 40182), P. drechsleri (KACC 40198) and P. erythoroseptica (KACC 40712) with known virulence against $C$. obtusa were obtained from Korean Agriculture Culture Collection (KACC; Suwon, Korea) for in vitro antagonistic assay with B. velezensis CE 100. These four phytopathogenic oomycetes were cultured in potato dextrose agar medium at $25^{\circ} \mathrm{C}$ for 10 days. Antagonistic activities of B. velezensis $\mathrm{CE} 100$ against these four phytopathogenic oomycetes were determined using the dual culture method. The bacterial antagonist was streaked onto one side of each agar plate. Then, a $5 \mathrm{~mm}$ plug of each phytopathogenic oomycete was made using a sterile cork borer and placed on the other side of the inoculated plate. Plates were then incubated at $25^{\circ} \mathrm{C}$. Depending on the growth rate of each pathogen, days of incubation were different: P. cinnamomi, 7 days; P. boehmeriae, P. drechsleri and P. erythoroseptica, 10 days. A plate inoculated with each oomycete pathogen alone was used as the control. The experiment was repeated three times with three replications per treatment. The growth inhibition of oomycete pathogens was calculated using the following formula: Inhibition $(\%)=[(\alpha-\beta) / \alpha] \times 100$, where $\alpha$ was the radial growth of phytopathogenic oomycete on the control plate and $\beta$ was the radial growth of phytopathogenic oomycete on the dual culture plate [24,26-28].

To examine the effects of $B$. velezensis CE 100 on hyphal morphologies of oomycete pathogens, a small piece of phytopathogenic oomycete hyphae at the boundary of the pathogen colony co-inhabited with B. velezensis CE 100 was taken and observed for hyphal deformation and degradation. Phytopathogenic oomycete mycelia were observed under a light microscope at 200× magnification (BX41TF Microscope, Olympus, Tokyo, Japan). All experiments for morphological observation of mycelia were performed in triplicate.

\subsection{Indole-3-Acetic Acid (IAA) Production by B. velezensis CE 100}

Quantitative analyses of IAA produced by $B$. velezensis CE 100 were performed using a UV spectrometric method, as described previously [50]. Briefly, B. velezensis CE 100 was cultured in a medium containing fertilizer $3 \mathrm{~g}, \mathrm{KH}_{2} \mathrm{PO}_{4} 0.2 \mathrm{~g}, \mathrm{MgSO}_{4} 0.2 \mathrm{~g}, \mathrm{NaCl}$ $0.1 \mathrm{~g}$, sucrose $3 \mathrm{~g}$, chitin powder $0.5 \mathrm{~g}$, yeast extract $0.6 \mathrm{~g}$ and $0.1 \mathrm{~g}$ L-tryptophan in $1 \mathrm{~L}$ distilled water. The culture was incubated at $30{ }^{\circ} \mathrm{C}$ in a shaking incubator at $140 \mathrm{rpm}$. Samples were taken every day from the day of inoculation. The samples were centrifuged at $12,000 \mathrm{rpm}$ for $10 \mathrm{~min}$ at $4{ }^{\circ} \mathrm{C}$. Then, $1 \mathrm{~mL}$ of the resulting supernatant was mixed with $2 \mathrm{~mL}$ of Salkowski's reagent. Subsequently, the reaction mixture was incubated at room 
temperature in the dark for $25 \mathrm{~min}$. The concentration of IAA in each sample was measured at $530 \mathrm{~nm}$ using a UV spectrometer (UV-1650PC, Shimadzu, Kyoto, Japan).

\subsection{Experimental Conditions}

The experiment was carried out with three replications in a greenhouse at Chonnam National University, Korea (approximately $35^{\circ} 17^{\prime} \mathrm{N}$ latitude, $126^{\circ} 90^{\prime} \mathrm{E}$ longitude) (Figure 1A). During the experiment, the temperature was maintained at $20-25^{\circ} \mathrm{C}$ all day using a heating and cooling system and light was provided using natural light. The experiment was conducted using 2 years old C. obtusa seedlings purchased from a seedling company in October 2019. Each seedling was approximately $15 \mathrm{~cm}$ high, and the root collar diameter was $1.5 \mathrm{~cm}$. The pots used were $20 \mathrm{~cm}$ in diameter and $25 \mathrm{~cm}$ in height. The pots were washed with $2 \% \mathrm{H}_{2} \mathrm{O}_{2}$ for sterilization and dried before use [51]. Seedlings were planted in approximately $500 \mathrm{~g}$ of potted soil mixture (vermiculite, sand, red soil, and topsoil = 1:2:1:1) at the study site in October 2019. The following three treatment groups were used in this experiment: control (without fertilizer or bacteria), chemical fertilizer and B. velezensis CE 100 inoculation. For each treatment, 20 replicates were used, and each replicate was repeated 3 times with a $100 \mathrm{~cm}$ buffer zone between the blocks. A total of 180 seedlings were used in the experiment, with 60 seedlings for each treatment group. To avoid position effect, seedlings of each treatment were moved every month. At one month after planting, bacterial inoculum cultured at $30^{\circ} \mathrm{C}$ for 7 days was applied to the root zone at a rate of $100 \mathrm{~mL} /$ seedling every 10 days. For chemical fertilizer, $3 \mathrm{~g}$ of pink fertilizer (NPK 20-20-20) in $1 \mathrm{~L}$ distilled water were applied to the root zone a rate of $100 \mathrm{~mL} /$ seedling every 10 days. Control seedlings received $100 \mathrm{~mL}$ of water per seedling every 10 days, without any bacteria or fertilizer. All treatments were applied from November 2019 to June 2020.

\subsection{Analysis of Survival Rate of C. obtusa Seedlings}

Survival rates of seedlings were surveyed from November 2019 to June 2020. Seedlings of $C$. obtusa were considered dead when their leaves and shoots were dried or absent. The survival rate was calculated as a percentage of surviving seedlings among total seedlings.

\subsection{Determination of Seedling Growth Parameters}

To determine seedling growth (root collar diameter and lengths of shoot and root) and seedling biomass (shoot and root dry weights), all live seedlings were taken to the Department of forest resources at Chonnam National University in June 2020. After carefully washing the root area to eliminate all media and debris, the root collar diameter and lengths of the shoots, and roots were measured, respectively. The shoots and roots were separated at the boundaries of the uppermost parts of root. To determine the biomass, the shoots and roots of each treatment were dried for $24 \mathrm{~h}$ in pre-weighed, moisture free paper bag at $105^{\circ} \mathrm{C}$, in a convection drying oven (VS-1202D4, Vision Scientific, Daejeon, Korea) and the dry weight measured [31].

\subsection{Statistical Analysis}

Statistical analyses were performed using SPSS (Statistical Package for the Social Sciences), version 25 (Armonk, NY, USA). All data were subjected to an analysis of variance (ANOVA). The mean values were compared using Fisher's Least Significant Difference (LSD) test at $p<0.01$.

\section{Results}

3.1. Inhibition of Root Rot Diseases Caused by Phytophthora spp. Using B. velezensis CE 100 3.1.1. Growth Pattern of B. velezensis CE 100

The growth of $B$. velezensis CE 100 increased slowly until 5 days after inoculation (Figure 2). Thereafter, the growth of $B$. velezensis CE 100 rapidly increased to a maximum value of $12.7 \times 10^{7} \mathrm{CFU} / \mathrm{mL}$ at 7 days after inoculation Then, the growth rate of 
B. velezensis CE 100 steadily decreased from 8 days after inoculation until the end of the experimental period.

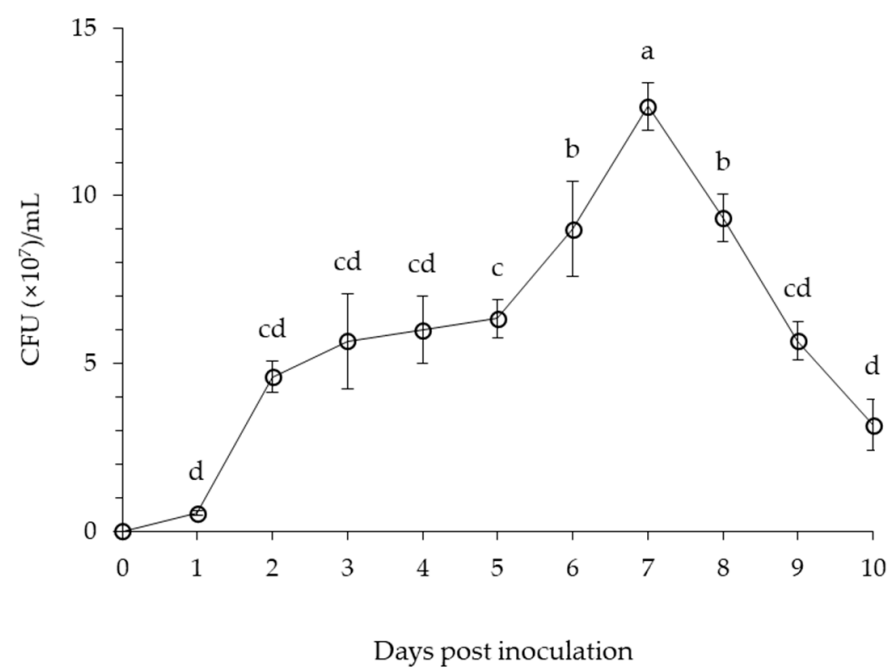

Figure 2. Cell growth curve of B. velezensis CE 100 in PB medium at $30^{\circ} \mathrm{C}$ for 10 days. Error bars represent the standard deviation of three replications. Means with the same letter are not significantly different at $p<0.01$ when compared using LSD test.

\subsubsection{Production of Lytic Enzymes by B. velezensis CE 100}

The production of lytic enzymes, such as $\beta$-1,3-glucanase and protease activities, was examined from the bacterial culture of $B$. velezensis CE 100 (Figure 3). The $\beta-1,3$-glucanase activity increased steadily for 6 days, eventually reaching a maximum value of $5.2 \mathrm{unit} / \mathrm{mL}$ at 7 days (Figure $3 \mathrm{~A}$ ). The activity of $\beta$-1,3-glucanase stabilized after 8 days of incubation at about 3 unit $/ \mathrm{mL}$ throughout the end of the study. In addition, B. velezensis CE 100 showed high protease activity during incubation. Protease activity rapidly increased to $10 \mathrm{unit} / \mathrm{mL}$ within $24 \mathrm{~h}$ after inoculation, and then increased gradually to $20 \mathrm{unit} / \mathrm{mL}$ in 5 days. Similar to the observed pattern in CFU, the activity of protease showed an exponential increase from 5 days to 7 days post inoculation, reaching a maximum value of 32.9 unit $/ \mathrm{mL}$ (Figure 3B). The activity then decreased until to about $10 \mathrm{unit} / \mathrm{mL}$ by the end of the incubation period.

A. $\beta-1,3-G l u c a n a s e$ activity

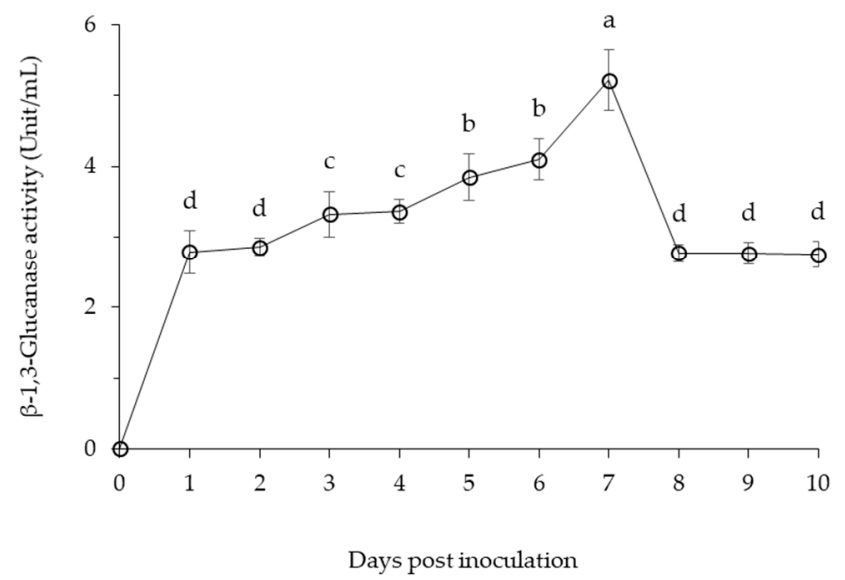

B. Protease activity

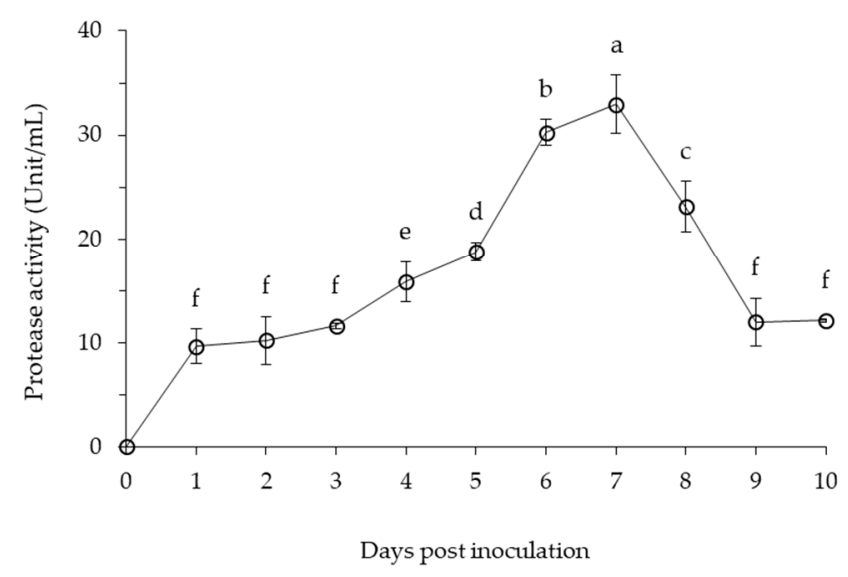

Figure 3. Changes in $\beta$-1,3-glucanase (A) and protease (B) activities in the culture supernatant of B. velezensis CE 100. Error bars represent the standard deviation of three replications. Means with the same letter are not significantly different at $p<0.01$ when compared using LSD test. 


\subsubsection{Inhibition of Oomycete Pathogens by B. velezensis CE 100}

Treatment with $B$. velezensis CE 100 showed strong anti-oomycete activity against phytopathogenic Phytophthora species used in this study (Figure 4). In a dual culture experiment, $B$. velezensis CE 100 inhibited the growth of each phytopathogenic oomycete as follows: P. boehmeriae, 54.6\%; P. cinnamomi, 62.6\%; P. drechsleri, $74.3 \%$; and P. erythoroseptica, $73.7 \%$ (Figure 4A). Light microscopic observations of the hyphae of these phytopathogenic oomycete indicated normal hyphal growth in the control group and abnormal growths, such as swelling and deformation of the mycelia in B. velezensis CE 100 treatment group (Figure 5).

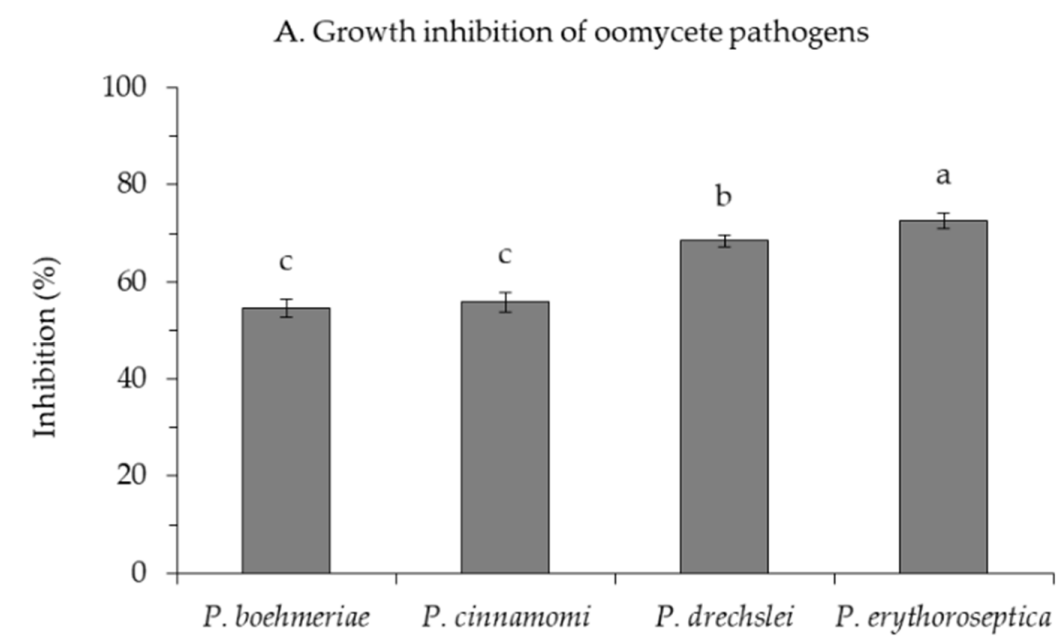

Phytopathogenic fungi

B. Antagonistic activity against oomycete pathogens

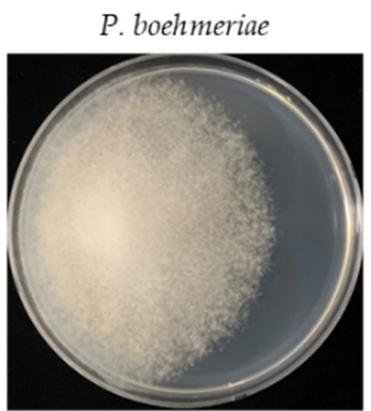

P. boehmeriae (left) and B. velezensis CE 100 (right)

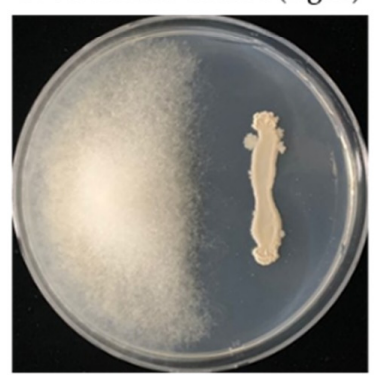

P. cinnamomi

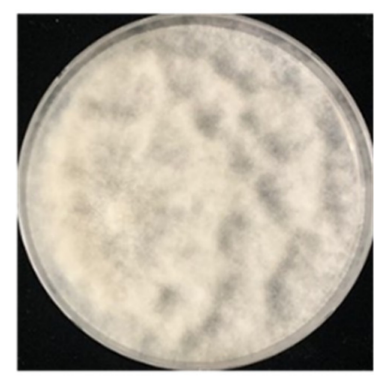

P. cinnamomi (left) and B. velezensis CE 100 (right)

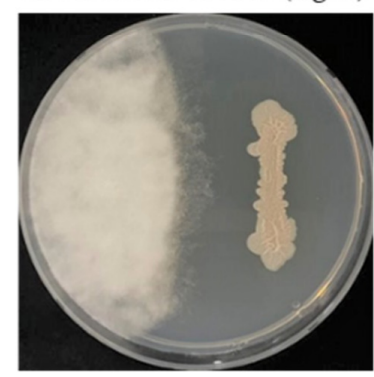

P. drechsleri

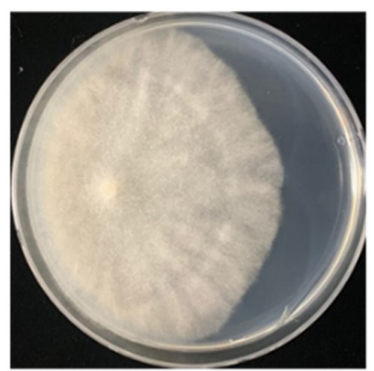

P. drechsleri (left) and B. velezensis CE 100 (right)

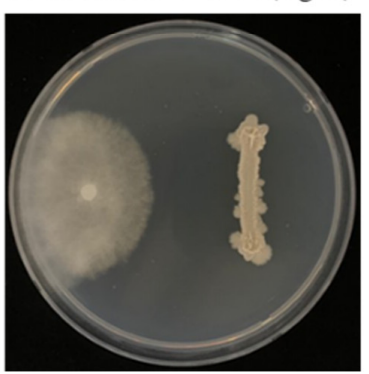

P. erythoroseptica

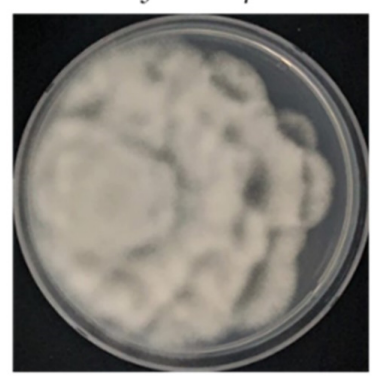

P. erythoroseptica (left) and B. velezensis CE 100 (right)

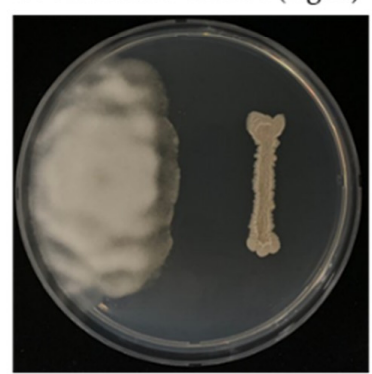

Figure 4. Inhibition effect of B. velezensis CE 100 on mycelial growth of P. boehmeriae, P. cinnamomi, P. drechsleri and P. erythoroseptica (A). Antagonistic activities of B. velezensis CE 100 against P. boehmeriae, P. cinnamomi, P. drechsleri and P. erythoroseptica (B) based on a dual culture method. Error bars represent the standard deviation of three replications. Means with the same letter are not significantly different at $p<0.01$ when compared using LSD test. 
P. boehmeriae

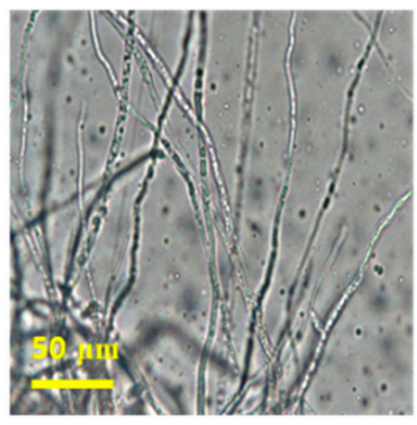

$P$. boehmeriae with
P. cinnamomi

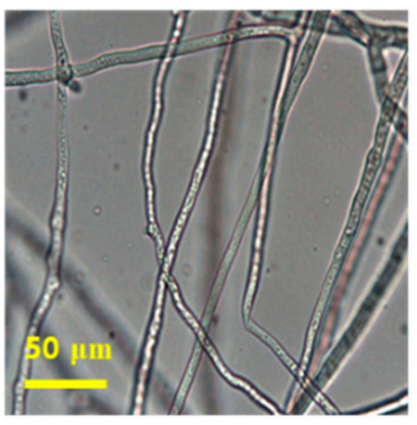

P. cinnamomi with
P. drechsleri

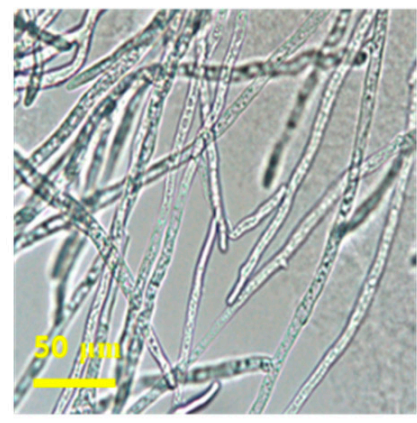

$P$. drechsleri with
P. erythoroseptica

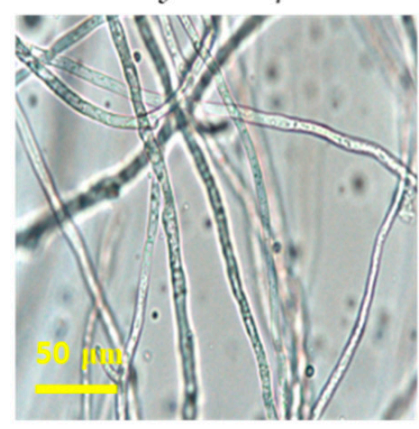

P. erythoroseptica with

B. velezensis CE 100 treatment $B$. velezensis CE 100 treatment $B$. velezensis CE 100 treatment $B$. velezensis $C E 100$ treatment
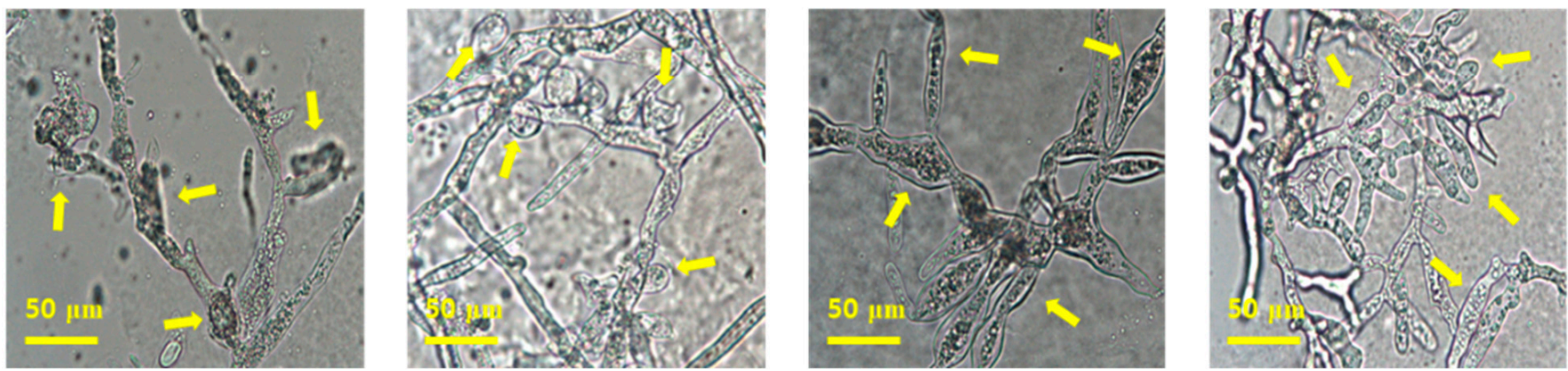

Figure 5. Inhibition effect of B. velezensis CE 100 on phytopathogenic hyphae morphologies of P. boehmeriae, P. cinnamomi, $P$. drechsleri and P. erythoroseptica, observed under a light microscope. On the top, the normal growth in the control group and at the bottom, the corresponding effect of B. velezensis CE 100. Arrows indicate hyphal alterations with swelling and deformation structures caused by B. velezensis CE 100.

\subsubsection{Survival Rate of C. obtusa Seedlings}

The average survival rate of $C$. obtusa seedlings inoculated with B. velezensis CE 100 was higher than that of seedlings in the control group and chemical fertilizer treatment (Table 1). In particular, the average survival rate of C. obtusa seedlings inoculated with B. velezensis CE 100 (81.7\%) in June 2020 was 2.0 -fold or 1.7 -fold higher than the survival rate of the seedlings in the control group (41.7\%) and chemical fertilizer treatment (48.3\%), respectively. There was no statistically significant difference between the survival rates in the control group and chemical fertilizer treatment.

Table 1. Average survival rates of C. obtusa seedlings under the different treatment groups from November 2019 to June 2020 in a greenhouse.

\begin{tabular}{|c|c|c|c|c|c|c|c|c|}
\hline \multirow{3}{*}{ Treatment } & \multicolumn{8}{|c|}{ Survival Rate (\%) } \\
\hline & \multicolumn{2}{|c|}{2019} & \multicolumn{6}{|c|}{2020} \\
\hline & November & December & January & February & March & April & May & June \\
\hline Control & $100 \pm 0.0^{\mathrm{a}}$ & $85.0 \pm 5.0^{b}$ & $78.3 \pm 5.8^{b}$ & $66.7 \pm 7.6^{b}$ & $51.7 \pm 7.6^{b}$ & $46.7 \pm 3.5^{b}$ & $45.0 \pm 8.7^{b}$ & $41.7 \pm 5.8^{b}$ \\
\hline $\begin{array}{l}\text { Chemical } \\
\text { fertilizer }\end{array}$ & $100 \pm 0.0^{\mathrm{a}}$ & $86.7 \pm 2.9^{b}$ & $81.7 \pm 5.8^{b}$ & $73.3 \pm 2.9^{b}$ & $60.0 \pm 5.0^{b}$ & $58.3 \pm 7.6^{b}$ & $53.3 \pm 5.8^{b}$ & $48.3 \pm 5.8^{b}$ \\
\hline $\begin{array}{l}\text { Bacterial } \\
\text { inoculation }\end{array}$ & $100 \pm 0.0^{\mathrm{a}}$ & $100 \pm 0.0^{\mathrm{a}}$ & $100 \pm 0.0^{\mathrm{a}}$ & $91.7 \pm 2.9^{\mathrm{a}}$ & $90.0 \pm 5.0^{\mathrm{a}}$ & $85.0 \pm 5.0^{\mathrm{a}}$ & $81.7 \pm 3.5^{\mathrm{a}}$ & $81.7 \pm 3.5^{\mathrm{a}}$ \\
\hline
\end{tabular}




\subsection{Effect of B. velezensis CE 100 on Growth Promotion of C. obtusa Seedlings}

3.2.1. Indole-3-Acetic Acid (IAA) Production of B. velezensis CE 100

Incubation of B. velezensis CE 100 produced auxin, IAA during growth (Figure 6). The IAA concentration steadily increased for 6 days, eventually reaching a maximum value of $183.7 \mathrm{mg} / \mathrm{L}$ on 7 days. Thereafter, the IAA concentration decreased gradually to approximately $100 \mathrm{mg} / \mathrm{mL}$ at the end of the study.

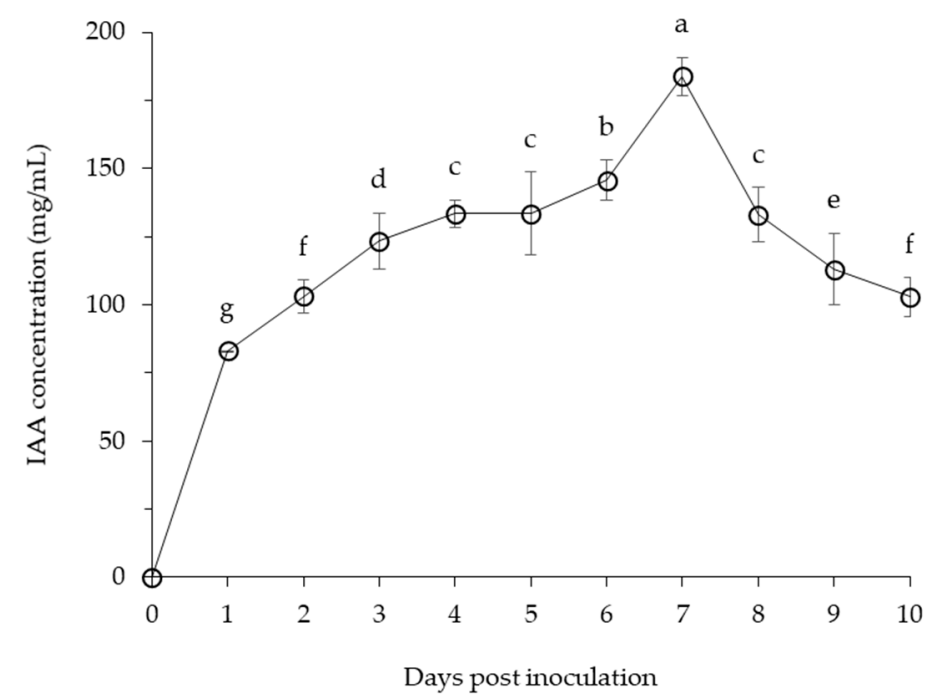

Figure 6. Changes in indole-3-acetic acid (IAA) concentration with B. velezensis CE 100. Error bars represent the standard deviation of three replications. The means with the same letter are not significantly different at $p<0.01$ when compared using LSD test.

\subsubsection{Growth and Biomass Yield of C. obtusa Seedlings}

Significant increases in the growth (root collar diameter and lengths of shoot and root) and biomass (dry weights of shoot and root) were observed in C. obtusa seedlings, inoculated with B. velezensis CE 100, compared to both the control group and chemical fertilizer treatment (Table 2). The average root collar diameter, shoot length and root length of seedlings inoculated with B. velezensis CE 100 were $3.2 \mathrm{~mm}, 32.6 \mathrm{~cm}$ and $15.5 \mathrm{~cm}$, respectively. Therefore, $B$. velezensis $C E 100$ increased collar diameter, shoot length and root length by 1.3, 1.4 and 1.5-folds, compared to the control group. The chemical fertilizer treatment also showed significantly higher root length compared to the control group, but no difference was observed with respect to the root collar diameter and shoot length.

Table 2. Growth and biomass of C. obtusa seedlings in the control and inoculation with B. velezensis CE 100 treatments.

\begin{tabular}{|c|c|c|c|c|c|}
\hline \multirow[b]{2}{*}{ Treatment } & \multicolumn{3}{|c|}{ Seedling Growth } & \multicolumn{2}{|c|}{ Seedling Biomass } \\
\hline & $\begin{array}{c}\text { Root Collar } \\
\text { Diameter (mm) }\end{array}$ & Shoot Length $(\mathrm{cm})$ & Root Length (cm) & Shoot Dry Weight (kg) & Root Dry Weight (kg) \\
\hline Control & $2.4 \pm 0.3^{b}$ & $23.8 \pm 2.3^{b}$ & $10.3 \pm 0.9^{c}$ & $13.8 \pm 1.7^{\mathrm{b}}$ & $3.1 \pm 0.2^{c}$ \\
\hline Chemical fertilizer & $2.6 \pm 0.4^{b}$ & $25.0 \pm 1.7^{b}$ & $12.4 \pm 1.4^{b}$ & $14.3 \pm 1.5^{b}$ & $3.7 \pm 0.4^{b}$ \\
\hline Bacterial inoculation & $3.2 \pm 0.2^{\mathrm{a}}$ & $32.6 \pm 1.5^{\mathrm{a}}$ & $15.5 \pm 0.9^{a}$ & $19.6 \pm 1.2^{\mathrm{a}}$ & $5.8 \pm 0.3^{a}$ \\
\hline
\end{tabular}

Letter indicates a significant difference between treatments significant at $p<0.01$ by LSD test.

In addition, the seedlings treated with bacterial inoculation had significantly higher biomass compared to the control group and chemical fertilizer. In particular, the dry weights of shoot and root of C. obtusa seedlings inoculated with B. velezensis CE 100 were 1.4, and 1.9-fold heavier than the control, respectively. The root dry weight was significantly higher in the chemical fertilizer treatment than in the control group, but no difference was observed in shoot dry weight. 


\section{Discussion}

4.1. Anti-Oomycete Activity of B. velezensis CE 100 against Phytophthora spp. and Survival Rate of Seedlings

Root rot diseases, caused by Phytophthora spp., are highly prevalent in forest soils and pose a major challenge in forest seedling production [12]. In this study, Phytophthora root rot diseases symptoms were observed in C. obtusa seedlings across the treatments, limiting the survival of seedlings (Table 1). Nonetheless, the survival rate of C. obtusa seedlings treated with B. velezensis CE 100 was 2.0 and 1.7-fold higher than that of the control group, and chemical fertilizer treatment, respectively (Table 1). Chemical fertilizer treatment and the control group were not statistically different in the survival rate of C. obtusa seedlings (Table 1). The use of chemical fertilizers increases the biomass of phytopathogens in the soil, which in turn increases the rate of seedling infection [52]. In the present study, $B$. velezensis CE 100 secreted cell wall-degrading enzymes such as $\beta-1,3$-glucanase and protease throughout the incubation period (Figure 3). Consequently, B. velezensis CE 100 showed strong inhibitory effects against the major oomycete pathogens associated to root rot diseases in C. obtusa seedlings: P. boehmeriae, 54.6\%; P. cinnamomi, 62.6\%; P. drechsleri, $74.3 \%$; and P. erythoroseptica, $73.7 \%$, in vitro (Figure 4). The hyphae of the phytopathogenic oomycetes in the group, treated with B. velezensis CE 100, showed an abnormal morphology, such as swelling and deformation under a light microscope (Figure 5). The cell wall of oomycete is composed of $80-90 \%$ glucan and $5-10 \%$ protein, which play an important role in maintaining cell wall integrity $[53,54]$. Cell wall degrading enzymes, produced by antagonistic bacteria, can exert a direct inhibitory effect on cell wall of many oomycete pathogens $[25,26,28,29]$. In particular, $\beta-1,3$-glucanase and protease are well-known for their ability to degrade and lyse the cell walls of oomycete $[25,26,28,29]$. The enzyme $\beta$-1,3-glucanase hydrolyzes substrates by sequentially cleaving glucose residues from the non-reducing end and cleaves linkages at random sites along the polysaccharide chain, releasing smaller oligosaccharides $[55,56]$. Protease activity involves the hydrolysis of one or more peptide bonds by adding water to liberate peptides or amino acids [57]. Consequently, these enzymes can degrade glycosidic bonds in the polysaccharide of cell wall, thereby reducing the growth of the cell wall, the tip of hyphae and the germination tube. They also cause morphological distortions, such as hyphal breakage and formation of sporadic, anomalous swelling along the surface of hyphae [25,26,54]. In a previous study, El-Sayed et al. [25] demonstrated that lytic enzymes produced by Pseudomonas species EA6 can hydrolyze of Phytophthora parasitica cell wall, which is consistent with results of this study.

\subsection{Effect of B. velezensis CE 100 on Growth Promotion of C. obtusa Seedlings}

Besides biocontrol activity, PGPR provides plants with phytohormones, such as auxin that plays an important role in regulating plant growth and development by causing cell elongation through cell differentiation and expansion $[23,24,34]$. In the chemical fertilizer treatment, the root length and root dry weight of $C$. obtusa were significantly higher than that of the control group (Table 2). This is due to the fact, that seedlings develop roots to absorb nutrients and water before the shoots, and the chemical fertilizer treatment group developed the roots more through the absorption of excellent nutrients [58]. However, the root collar diameter, shoot length and shoot dry weight were not significantly different between the chemical fertilizer treatment and the control group (Table 2). This could be due to phytophthora root rot diseases, which cause necrosis in the inner bark of the root $[12,18]$. Necrosis reduces the ability of the root system to absorb and transport water and nutrients, which leads to retardation and consequently, the seedlings fail to attain the expected stage in shoot growth [59]. However, C. obtusa seedlings inoculated with B. velezensis CE 100 showed significant increases in growth and biomass, compared with the control group and chemical fertilizer treatment (Table 2). Therefore, B. velezensis CE 100 controlled phytophthora root rot in $C$. obtusa seedlings by secreting lytic enzymes such as $\beta-1,3$-glucanase and protease. This resulted in healthy seedlings with a well-developed root system to absorb and 
transport water and nutrients, which enhanced seedling growth. In addition, $B$. velezensis CE 100 secreted IAA into the medium to a concentration $183.7 \mathrm{mg} / \mathrm{mL}$ (Figure 6). The secretion of auxin could have enhanced shoot and root lengths (Table 2), as well as initiating lateral and adventitious root formation as observed (Figure 1C). Auxin can activate plasma membrane $\mathrm{H}^{+}$-ATPase proton pumps, which pump protons $\left(\mathrm{H}^{+}\right)$into the wall matrix, leading to wall acidification within $\mathrm{pH}$ between 4.5 and 6 [37-39]. The acidification of cell walls accelerates structural proteins such as EXPANSINs (EXPs), EXTENSINs (EXTs) and ARABINOGALACTAN PROTEINs (AGPs) [37-39]. As non-enzymatic wall-loosening proteins, EXPs can loosen the cell wall structure by breaking the hydrogen bond between cellulose microfibrils and hemicelluloses that connect them [37-39]. The activation of plasma membrane $\mathrm{H}^{+}$-ATPase causes hyperpolarization of the membrane potential and activation of voltage-dependent $\mathrm{K}^{+}$inward, which transport potassium ions $\left(\mathrm{K}^{+}\right)$to the cytosol, thus, stimulating water $\left(\mathrm{H}_{2} \mathrm{O}\right)$ uptake and maintaining tensile stress [39]. As a result, the cell wall increases, causing cells to expand and become larger, which increases length of roots [39]. In addition, auxin provides a key signal during lateral root development, triggering the initial mitotic division of lateral root founder cells in the pericycle tissue to form lateral and adventitious roots $[60,61]$. Finally, root development can increase the surface area of root systems in contact with soil and lead to an increased ability for nutrient and water uptake, ultimately improving plant growth and yield. Park et al. [35] demonstrated that auxin produced by Bacillus licheniformis MH48 can increase dry weights of leaves and roots of Camellia japonica seedlings by 2.6, and 2.2-fold, respectively, compared to the control. Indeed, the results of this study clearly indicate that treatment with B. velezensis CE 100 bacterial inoculation significantly increased seedling growth and biomass production compared to chemical fertilizer treatment and the control group. The bacterial inoculation was particularly beneficial for improved root length and root collar diameter, which ultimately increased the surface area for nutrient uptake, leading to increased growth and biomass production in C. obtusa seedlings.

\section{Conclusions}

The results of the study suggest that, the antagonistic bacteria, B. velezensis CE 100 produces lytic enzymes, such as $\beta$-1,3-glucanase and protease. These lytic enzymes degraded the cell walls, and effectively controlled the growth of phytopathogenic phytophthora spp., the causative agent of root rot diseases in C. obtusa seedlings. Consequently, treatment with $B$. velezensis CE 100 suppressed the prevalence of phytophthora root rot diseases and enhanced the survival rate of $C$. obtusa seedlings in the greenhouse. In addition, the secretion of auxin, such as IAA by B. velezensis CE 100 could have increased the growth of $C$. obtusa seedlings through cell expansion and differentiation, resulting in increased growth and biomass production. Therefore, this study demonstrates that $B$. velezensis $C E$ 100 is reliable biocontrol agent against Phytophthora spp., and could be effectively used in the management of root rot diseases, as well as the growth promotion of $C$. obtusa seedlings.

Author Contributions: Conceptualization, funding acquisition and project administration, Y.S.A.; investigation and experiments, J.-H.M., C.E.H.M., S.-J.W., J.-H.C. and S.-I.C.; data analysis, J.-H.M., C.E.H.M. and S.-J.W.; original draft preparation, J.-H.M., H.B.A. and Y.S.A.; review and editing, J.-H.M., H.B.A. and Y.S.A. All authors have read and agreed to the published version of the manuscript.

Funding: This study was supported by the R\&D program for Forest Science Technology (Project No. 2020183C10-2022-AA02) funded by the Korea Forest Service (Korea Forestry Promotion Institute).

Institutional Review Board Statement: Not applicable.

Informed Consent Statement: Not applicable.

Data Availability Statement: Data are available on request from the corresponding author.

Acknowledgments: The authors would like to acknowledge Young Sang Ahn for the tutorial support. 
Conflicts of Interest: The authors have no conflicts of interest relevant to this study to disclose. The funders had no role in the design of the study; in the collection, analyses, or interpretation of data; in the writing of the manuscript; or in the decision to publish the results.

\section{References}

1. Matsumoto, A.; Tani, N.; LI, X.G.; Nakao, Y.; Tomaru, N.; Tsumura, Y. Development and polymorphisms of microsatellite markers for hinoki (Chamaecyparis obtusa). Mol. Ecol. Resour. 2006, 6, 310-312. [CrossRef]

2. Tian, M.; Han, D.; Row, K.H. Preparation of molecularly imprinted polymer for extracting flavones from Chamaecyparis obtusa. Anal. Lett. 2011, 44, 737-746. [CrossRef]

3. Tang, B.; Bi, W.; Zhang, H.; Row, K.H. Deep eutectic solvent-based HS-SME coupled with GC for the analysis of bioactive terpenoids in Chamaecyparis obtusa leaves. Chromatographia 2014, 77, 373-377. [CrossRef]

4. Ikei, H.; Song, C.; Miyazaki, Y. Physiological effect of olfactory stimulation by Hinoki cypress (Chamaecyparis obtusa) leaf oil. J. Physiol. Anthropol. 2015, 34, 1-7. [CrossRef] [PubMed]

5. Shik, M.H.; Woon, K.T.; Solomon, T. Growth Performance Assessment of Chamaecyparis obtusa Stand in Gyeongnam Province, S. Korea. Agric. For. Fish. 2020, 9, 135-141. [CrossRef]

6. Forestry Statistical Yearbook. Available online: https://www.forest.go.kr/kfsweb/cop/bbs/selectBoardArticle.do;jsessionid= Nz0iyNG4B4kBJtjOhIQQ0yvThcQPtZTF9QxCU93XBxDKK9gYJhZblMP19SFGqLuy.frswas01_servlet_engine5?nttId=31 50759\&bbsId=BBSMSTR_1064\&pageIndex=1\&pageUnit=10\&searchtitle=title\&searchcont=\&searchkey=\&searchwriter= \&searchdept=\&searchWrd=\&ctgryLrcls=\&ctgryMdcls=\&ctgrySmcls=\&ntcStartDt=\&ntcEndDt=\&orgId=\&mn=NKFS_04_05_ 09\&component $=$ (accessed on 2 November 2020).

7. Heiskanen, J. Effects of compost additive in sphagnum peat growing medium on Norway spruce container seedlings. New For. 2013, 44, 101-118. [CrossRef]

8. Ghorbani, R.; Wilcockson, S.; Koocheki, A.; Leifert, C. Soil management for sustainable crop disease control: A review. Environ. Chem. Lett. 2008, 6, 177-201. [CrossRef]

9. Paungfoo-Lonhienne, C.; Yeoh, Y.K.; Kasinadhuni, N.R.P.; Lonhienne, T.G.; Robinson, N.; Hugenholtz, P.; Ragan, M.A.; Schmidt, S. Nitrogen fertilizer dose alters fungal communities in sugarcane soil and rhizosphere. Sci. Rep. 2015, 5, 1-6. [CrossRef]

10. Yuan, Z.Y.; Chen, H.Y. Negative effects of fertilization on plant nutrient resorption. Ecology 2015, 96, 373-380. [CrossRef]

11. Robin, C.; Piou, D.; Feau, N.; Douzon, G.; Schenck, N.; Hansen, E.M. Root and aerial infections of Chamaecyparis lawsoniana by Phytophthora lateralis: A new threat for European countries. For. Pathol. 2011, 41, 417-424. [CrossRef]

12. Jung, T.; Chang, T.T.; Bakonyi, J.; Seress, D.; Pérez-Sierra, A.; Yang, X.; Hong, C.; Scanu, B.; Fu, C.H.; Hsueh, K.L.; et al Diversity of Phytophthora species in natural ecosystems of Taiwan and association with disease symptoms. Plant Pathol. 2017, 66, 194-211. [CrossRef]

13. Thines, M. Taxonomy and Phylogeny of Phytophthora and Related Oomycetes. In Phytophthora: A Global Perspective; Lamour, K., Ed.; CAB International: Oxfordshire, UK, 2013; Volume 2, pp. 11-18.

14. Mora-Sala, B.; Gramaje, D.; Abad-Campos, P.; Berbegal, M. Diversity of Phytophthora species associated with Quercus ilex L. in three Spanish regions evaluated by NGS. Forests 2019, 10, 979. [CrossRef]

15. Orlikowski, L.B. Occurrence and harmfulness of Phytophthora spp. in Polish hardy ornamental nursery stock. Acta Hortic. 2010, 885, 243-248. [CrossRef]

16. Chastagner, G.A.; Benson, D.M. The Christmas tree: Traditions, production and diseases. Plant Health Prog. 2000, 1, 1-15. [CrossRef]

17. Widmer, T.L. Infective potential of sporangia and zoospores of Phytophthora ramorum. Plant Dis. 2009, 93, 30-35. [CrossRef]

18. Hansen, E.M. Phytophthora species emerging as pathogens of forest trees. Curr. For. Rep. 2015, 1, 16-24. [CrossRef]

19. Fernández-Acero, F.J.; Carbú, M.; Garrido, C.; Collado, I.G.; Cantoral, J.; Vallejo, I. Screening Study of Potential Lead Compounds for Natural Product-based Fungicides Against Phytophthora Species. J. Phytopathol. 2006, 154, 616-621. [CrossRef]

20. Grünwald, N.J.; Sturbaum, A.K.; Montes, G.R.; Serrano, E.G.; Lozoya-Saldaña, H.; Fry, W.E. Selection for fungicide resistance within a growing season in field populations of Phytophthora infestans at the center of origin. Phytopathology 2006, 96, 1397-1403. [CrossRef]

21. Nguyen, X.H.; Naing, K.W.; Lee, Y.S.; Kim, Y.H.; Moon, J.H.; Kim, K.Y. Antagonism of antifungal metabolites from Streptomyces griseus H7602 against Phytophthora capsici. J. Basic Microbiol. 2015, 55, 45-53. [CrossRef]

22. Wightwick, A.; Walters, R.; Allinson, G.; Reichman, S.; Menzies, N. Environmental Risks of Fungicides Used in Horticultural Production Systems. In Fungicides; Carisse, O., Ed.; IntechOpen: Rijeka, Croatia, 2010; pp. 273-304. [CrossRef]

23. Glick, B.R. Plant growth-promoting bacteria: Mechanisms and applications. Scientifica 2012, 2012, 1-15. [CrossRef]

24. Goswami, D.; Thakker, J.N.; Dhandhukia, P.C. Portraying mechanics of plant growth promoting rhizobacteria (PGPR): A review. Cogent Food Agric. 2016, 2, 1-19. [CrossRef]

25. El-Sayed, A.S.; Akbar, A.; Iqrar, I.; Ali, R.; Norman, D.; Brennan, M.; Ali, G.S. A glucanolytic Pseudomonas sp. associated with Smilax bona-nox L. displays strong activity against Phytophthora parasitica. Microbiol. Res. 2018, 207, 140-152. [CrossRef] [PubMed]

26. Sowanpreecha, R.; Rerngsamran, P. Biocontrol of orchid-pathogenic mold, Phytophthora palmivora, by antifungal proteins from Pseudomonas aeruginosa RS1. Mycobiology 2018, 46, 129-137. [CrossRef] [PubMed] 
27. Guo, D.; Yuan, C.; Luo, Y.; Chen, Y.; Lu, M.; Chen, G.; Ren, G.; Cui, C.; Zhang, J.; An, D. Biocontrol of tobacco black shank disease (Phytophthora nicotianae) by Bacillus velezensis Ba168. Pestic. Biochem. Physiol. 2020, 165, 104523. [CrossRef]

28. Singh, D.; Ghosh, P.; Kumar, J.; Kumar, A. Rhizosphere, Microbiome and Agro-ecology. In Microbial Interventions in Agriculture and Environment, 1st ed.; Singh, D.P., Gupta, V.K., Prabha, R., Eds.; Springer Nature: Singapore, 2019; pp. 205-227. [CrossRef]

29. Safitri, D.; Wiyono, S.; Soekarno, B.P.W.; Achmad, A. Epiphytic yeasts from Piperaceae as biocontrol agents for foot rot of black pepper caused by Phytophthora capsici. Bio diversitas 2021, 22, 1895-1901. [CrossRef]

30. Kwon, J.H.; Won, S.J.; Moon, J.H.; Kim, C.W.; Ahn, Y.S. Control of Fungal Diseases and Increase in Yields of a Cultivated Jujube Fruit (Zizyphus jujuba Miller var. inermis Rehder) Orchard by Employing Lysobacter antibioticus HS124. Forests 2019, 10, 1146. [CrossRef]

31. Won, S.-J.; Choub, V.; Kwon, J.-H.; Kim, D.-H.; Ahn, Y.S. The Control of Fusarium Root Rot and Development of Coastal Pine (Pinus thunbergii Parl.) Seedlings in a Container Nursery by Use of Bacillus licheniformis MH48. Forests 2018, 10, 6. [CrossRef]

32. Won, S.-J.; Kwon, J.-H.; Kim, D.H.; Ahn, Y.S. The effect of Bacillus licheniformis MH48 on control of foliar fungal diseases and growth promotion of Camellia oleifera seedlings in the coastal reclaimed land of Korea. Pathogens 2019, 8, 6. [CrossRef]

33. Egorshina, A.A.; Khairullin, R.M.; Sakhabutdinova, A.R.; Luk'Yantsev, M.A. Involvement of phytohormones in the development of interaction between wheat seedlings and endophytic Bacillus subtilis strain 11BM. Russ. J. Plant Physiol. 2012, 59, 134-140. [CrossRef]

34. Ahmed, A.; Hasnain, S. Auxins as one of the factors of plant growth improvement by plant growth promoting rhizobacteria. Pol. J. Microbiol. 2014, 63, 261-266. [CrossRef]

35. Park, H.-G.; Jeong, M.-H.; Ahn, Y.S. Inoculation with Bacillus licheniformis MH48 to improve Camellia japonica seedling development in coastal lands. Turk. J. Agric. For. 2017, 41, 381-388. [CrossRef]

36. Kang, X.; Zhang, W.; Cai, X.; Zhu, T.; Xue, Y.; Liu, C. Bacillus velezensis CC09: A potential 'vaccine' for controlling wheat diseases. Mol. Plant Microbe Interact. 2018, 31, 623-632. [CrossRef]

37. Tanimoto, E. Regulation of root growth by plant hormones-roles for auxin and gibberellin. Crit. Rev. Plant Sci. 2005, 24, 249-265. [CrossRef]

38. Perrot-Rechenmann, C. Cellular responses to auxin: Division versus expansion. Cold Spring Harb. Perspect. Biol. 2010, 2, 1-15. [CrossRef] [PubMed]

39. Majda, M.; Robert, S. The role of auxin in cell wall expansion. Int. J. Mol. Sci. 2018, 19, 951. [CrossRef] [PubMed]

40. Akgül, D.S.; Mirik, M. Biocontrol of Phytophthora capsici on pepper plants by Bacillus megaterium strains. J. Plant Pathol. 2008, 90, 29-34. [CrossRef]

41. Lim, J.H.; Kim, S.D. Biocontrol of Phytophthora blight of red pepper caused by Phytophthora capsici using Bacillus subtilis AH18 and B. licheniformis K11 formulations. J. Korean Soc. Appl. Biol. Chem. 2010, 53, 766-773. [CrossRef]

42. Anjum, M.Z.; Ghazanfar, M.U.; Hussain, I. Bio-efficacy of Trichoderma isolates and Bacillus subtilis against root rot of muskmelon Cucumis Melo L. caused by Phytophthora drechsleri under controlled and field conditions. Pak. J. Bot. 2019, 51, 1877-1882. [CrossRef]

43. Grossnickle, S.C.; MacDonald, J.E. Why seedlings grow: Influence of plant attributes. New For. 2018, 49, 1-34. [CrossRef]

44. Sukhbaatar, G.; Ganbaatar, B.; Jamsran, T.; Purevragchaa, B.; Nachin, B.; Gradel, A. Assessment of early survival and growth of planted Scots pine (Pinus sylvestris) seedlings under extreme continental climate conditions of northern Mongolia. J. For. Res. 2020, 31, 13-26. [CrossRef]

45. Close, D.C.; Paterson, S.; Corkrey, R.; McArthur, C. Influences of seedling size, container type and mammal browsing on the establishment of Eucalyptus globulus in plantation forestry. New For. 2010, 39, 105-115. [CrossRef]

46. Choi, T.G.; Maung, C.E.H.; Lee, D.R.; Henry, A.B.; Lee, Y.S.; Kim, K.Y. Role of bacterial antagonists of fungal pathogens, Bacillus thuringiensis KYC and Bacillus velezensis CE 100 in control of root-knot nematode, Meloidogyne incognita and subsequent growth promotion of tomato. Biocontrol. Sci. Technol. 2020, 30, 685-700. [CrossRef]

47. Lee, D.-R.; Maung, C.E.H.; Henry, A.; Kim, K.-Y. Effect of large-scale cultivation of Bacillus amlyoliquefaciens Y1 using fertilizer based medium for control of Citrus Melanose causing Diaporthe citri. Korean J. Soil. Sci. Fert. 2019, 52, 84-92. [CrossRef]

48. Ghorbel-Frikha, B.; Sellami-Kamoun, A.; Fakhfakh, N.; Haddar, A.; Manni, L.; Nasri, M. Production and purification of a calcium-dependent protease from Bacillus cereus BG1. J. Ind. Microbiol. Biotechnol. 2005, 32, 186-194. [CrossRef] [PubMed]

49. Liang, Z.C.; Hseu, R.S.; Wang, H.H. Partial purification and characterization of a 1,3- $\beta$-d-glucanase from Ganoderma tsugae. J. Ind. Microbiol. 1995, 14, 5-9. [CrossRef]

50. Rahman, A.; Sitepu, I.R.; Tang, S.Y.; Hashidoko, Y. Salkowski's reagent test as a primary screening index for functionalities of rhizobacteria isolated from wild dipterocarp saplings growing naturally on medium-strongly acidic tropical peat soil. Biosci. Biotechnol. Biochem. 2010, 74, 2202-2208. [CrossRef] [PubMed]

51. Medina-cÓrdoba, L.K.; Valencia-Mosquera, L.L.; Tarazona-diaz, G.P.; Arias-palacios, J.D.C. Evaluation of the efficacy of a hydrogen peroxide disinfectant. Int. J. Pharm. Pharm. Sci. 2018, 10, 104-108. [CrossRef]

52. Aira, M.; Gómez-Brandón, M.; Lazcano, C.; Bååth, E.; Domínguez, J. Plant genotype strongly modifies the structure and growth of maize rhizosphere microbial communities. Soil Biol. Biochem. 2010, 42, 2276-2281. [CrossRef]

53. Hardham, A.R. Cell biology of plant-oomycete interactions. Cell. Microbiol. 2007, 9, 31-39. [CrossRef]

54. Mélida, H.; Sandoval-Sierra, J.V.; Diéguez-Uribeondo, J.; Bulone, V. Analyses of extracellular carbohydrates in oomycetes unveil the existence of three different cell wall types. Eukaryot. Cell 2013, 12, 194-203. [CrossRef] 
55. Noronha, E.F.; Ulhoa, C.J. Purification and characterization of an endo- $\beta-1,3-$ glucanase from Trichoderma harzianum. Can. J. Microbiol. 1996, 42, 1039-1044. [CrossRef]

56. Kaur, R.; Kalia, A.; Lore, J.S.; Sandhu, J.S. Antifungal effect of Trichoderma spp. $\beta$-1,3-glucanase on Phytophthora parasitica: Hyphal morphological distortions. J. Phytopathol. 2020, 168, 700-706. [CrossRef]

57. Thomas, E.L.; Van der Hoorn, R.A. Ten prominent host proteases in plant-pathogen interactions. Int. J. Mol. Sci. 2018, 19, 639. [CrossRef]

58. Mašková, T.; Herben, T. Root: Shoot ratio in developing seedlings: How seedlings change their allocation in response to seed mass and ambient nutrient supply. Ecol. Evol. 2018, 8, 7143-7150. [CrossRef]

59. Jung, T.; Pérez-Sierra, A.; Durán, A.; Jung, M.H.; Balci, Y.; Scanu, B. Canker and decline diseases caused by soil-and airborne Phytophthora species in forests and woodlands. Persoonia 2018, 40, 182-220. [CrossRef]

60. Overvoorde, P.; Fukaki, H.; Beeckman, T. Auxin control of root development. Cold Spring Harb. Perspect. Biol. 2010, 2, 1-16. [CrossRef]

61. Jing, H.; Strader, L.C. Interplay of auxin and cytokinin in lateral root development. Int. J. Mol. Sci. 2019, $20,486$. [CrossRef] [PubMed] 